결핵 연구원

류 우 진

\title{
The Up-to-date of Anti-Tuberculosis Treatment
}

\section{Lew Woo-Jin}

Korean Institute of Tuberculosis

\section{1. 서 론}

1970년 대에 rifampicin (RFP)과 pyrazinamide (P$\mathrm{ZA}$ )이 초치료 처방에 포함되면서 치료 기간이 6 개월 까지 단축시킬 수 있었으나, 그 후 30여년이 지난 오 늘날까지 균양성 폐결핵 환자의 치료 기간을 더욱 짧 게 단축시킬 수 있는 새로운 약제들이 개발되지 않고 있다. 제약 회사들이 새로운 항결핵제 개발에 관심을 덜 갖는 주된 이유는, 기존의 항결핵제들 만으로도 결핵을 완치시킬 수 있으며 또한 새로운 약제의 개발 로 얻을 수 있는 이득이 크지 않다고 생각하기 때문 이다. 이러한 이유 외에도 결핵균의 멸균적 치료를 방 해하는 휴면 상태로서 수년 혹은 수 십년간 존재할 수 있는 결핵균의 복잡한 대사 기전에 대한 지식 부 족도 이 문제를 해결할 수 있는 새로운 화합 물질을 찾는데 어려움을 주고 있다.

그럼에도 불구하고 오늘날 새로운 항결핵제의 개 발이 필요한 이유는 다음과 같이 세가지가 있다. 첫 째, 과거에 비하여 치료 기간이 6 개월로 단축되긴 하 였지만 아직도 6 개월이라는 기간은 환자의 불순응 (nonadherence)이 치료 결과에 영향을 줄 정도로 긴 시간이다. 환자의 불순응 문제의 해결책으로 직접감 독치료(DOT: Directly Observed Therapy)를 널리 권하고 있지만, DOT를 모든 결핵 환자에게 적용하기 에는 행정적, 비용적 부담이 너무 크다는 걸림돌이 있 다 둘째, 오늘날 심각한 문제가 되고 있는 다제내성

Address for correspondence : Woojin Lew, M.D., Korean Institute of Tuberculosis

14 Woomyundong, Sochogu, Seoul 137-900, Korea Phone : +82-2-572-0709 Fax : +82-2-573-1914

E-mail : wjlew@hanmail.net
결핵을 치료하기 위해서는 상대적으로 덜 효과적이 고 더 부작용이 많고 더 비싼 소위 2차 항결핵제로 최 소 18-24개월 동안 장기간 치료를 해야만 한다. 따 라서 다제내성 결핵의 치료 효율을 향상시킬 수 있는 새로운 약제 개발이 절실하다. 마지막으로, 결핵 퇴치 전략(elimination strategy)을 위하여 잠복 결핵을 치 료할 수 있는 보다 효과적이고 부작용이 적고 단기간 동안 사용할 수 있는 새로운 약제의 개발도 요구되 고 있다. 희소식은 최근에 결핵균의 DNA 염기서열이 밝혀지면서 새로운 약제의 표적을 찾을 수 있는 가능 성이 열린 것이다 ${ }^{2}$.

본 종설에서는 표1에 나열된 약제들 중 미래의 결 핵 약제로서의 가능성은 거론되고 있으나 아직은 결 핵 약제로서의 치료 효과가 검증되지 않은 새로운 약 제들과, 결핵균에 대한 숙주의 면역 반응을 강화하거 나 반대로 면역매개 염증 반응을 하향 조절하여 결핵 의 완치를 촉진하면서 또한 조직의 손상을 줄이고 증 상도 호전시키고자 시도된 일부 면역 치료제 등을 중 심으로 간략하게 살펴보고자 한다.

\section{2. 새로운 약제}

\section{1) Rifamycin}

rifamycin 계의 대표적인 약제는 rifampicin으로 1966년에 임상에 처음으로 사용되기 시작하면서 결 핵 치료에 획기적인 발전을 가져왔다. 같은 계통의 약 제인 rifabutin (ansamycin)이 1982년에 미국에서 소 개되면서 임상에서 사용되기 시작하였는데, 현재는 주로 HIV양성인 결핵 환자에서 항레트로바이러스 약 제와의 상호 작용으로 rifampicin을 사용할 수 없는 환자에서 대신 사용되고 있다. 
rifampicin에 내성을 보이는 결핵 환자의 치료에 rifabutin을 사용해도 치료 성적이 좋지 않는데, 그 이 유는 결핵균이 RNA-중합효소 염색체의 돌연변이를 통하여 내성을 획득하는데, 이 내성이 rifamycin 계통 의 모든 약제들에게도 전달되기 때문이다. 그러나 약 $10 \%$ 정도의 결핵균에서는 rifampicin에는 내성이나 rifabutin에는 내성을 보이지 않는데 ${ }^{3}$, 우리나라의 조 사 결과는 약 $20 \%$ 정도 내외를 보이고 있어제한적이 지만 일부 다제 내성환자에서는 rifabutin을 사용할 수도 있을 가능성이 있다.

rifapentine은 1998년에 미국식품의약청에서 허가 를 받았으며, 약동학적으로 rifampicin과 rifabutin에 비하여 혈청최대농도 $(\mathrm{Cmax})$ 가 가장 높고, 최소발육 저지농도(MICS)가 가장 낮고, 혈청반감기가 가장 길 어 DOT를 위한 주1회 간헐 요법에 가장 널리 사용되 고 있다 ${ }^{5}$.

\section{2) Fluoroquinolones}

이 약제들은 일반적인 광범위 항생제로 개발되었 지만, 오늘날 다제내성 결핵 환자의 치료 처방에 주사 제와 함께 필수적인 약제로까지 간주될 정도로 그 항 결핵 작용이 널리 알려져 이제는 2 차 항결핵 약제로 당당히 포함되게 되었다. ${ }^{6}$ 한편 ofloxacin을 1 차 항결 핵제로 사용하여 치료 기간을 단축시켜보려는 연구 가 시도되었는데, 이 약제를 기존의 isoniazid, rifampicin, pyrazinamide와 함께 3개월의 집중치료기를 거 친 후 isoniazid와 rifampicin만의 1 혹은 2 개월의 유 지치료기, 즉 전체 치료기간을 4 혹은 5 개월로 했을 때 2 년 재발율이 각각 $4 \%$ 와 $2 \%$ 라는 보고가 있어 치 료기간 단축의 가능성을 보여주었다.
이 약제들은 결핵균의 DNA gyrase라는 유전자 전 사와 복제에 관여하는 효소를 억제하여 항결핵제로 서의 작용을 나타내며, 약제 내성을 보이는 주 기전은 DNA gyrase의 subunit A (gyrA)의 돌연변이가 약 물의 작용을 방해하기 때문이다.

항결핵제로서의 임상 경험은 ofloxacin과 ciprofloxacin 약제가 가장 많이 축적되었는데, ciproflo xacin의 조기살균력은 isoniazid 만큼 현저하지 못하 며 ofloxacin보다도 낮은 것으로 알려져 있다. $\mathrm{lev}^{-}$ ofloxacin, moxifloxacin, 그리고 gatifloxacin은 시험 관내에서나 생체내에서 항결핵제로서 탁월한 효과를 보이고 있으며, 그 동안의 축적된 임상 경험에 근거하 여 levofloxacin 약제는 장기간의 사용에도 안전성을 보여 항결핵제로서 우선적으로 추천되고 있다. 최근 연구에 의하면 moxifloxacin의 조기살균력은 isoniazid와 큰 차이가 없으며 전반적인 항결핵제로서의 작용은 rifampicin에 버금간다고 한다 ${ }^{9}$.

그러나 fluoroquinolones 은 여러 호흡기 병원체 특 히 지역사회 획득폐렴의 치료에도 널리 사용되는 항 생제이고 동시에 결핵 환자에서도 fluoroquinolones 단독 치료에도 불과 3일 만에도 빠른 임상 호전을 보 일 수 있기 때문에 결핵을 폐렴으로 오진할 위험성이 있다. 이는 곧 결핵의 늦은 진단과 항생제의 내성으로 이어져 결핵의 유병률과 사망률을 높일 수 있으며, 또 한 항결핵제로서의 fluoroquinolones 약제의 유용성 이 제한될 수 있다. 이를 어느정도 예방할 수 있는 방 법으로 폐렴을 의심하여 치료를 시작할 때는 치료전 에 반드시 결핵균 검사 및 약제감수성 검사도 시행 하도록 권하고 있다 ${ }^{10}$.

\section{표1. 항결핵 약제}

\begin{tabular}{lll}
\hline \multicolumn{1}{c}{ 1차 결핵 약제 } & \multicolumn{1}{c}{ 2차 결핵 약제 } & \multicolumn{1}{c}{ 새로운 약제 } \\
\hline Isoniazid & PAS & Clofazimine \\
Rifampicin & Prothionamide/ Ethionamide & Amoxicillin/clavulanic acid \\
Pyrazinamide & Cycloserine & Clarithromycin/Azithromycin \\
Ethambutol & Kanamycin/ Amikacin & Rifabutin/ Rifapentine \\
Streptomycin & Capreomycin & Oxazolidinone: \\
& Ofloxacin/ Levofloxacin & - PNU-100480 (eperezolid) \\
& & - PNU-100766 (linezolid) \\
& & Nitroimidazopyrans: \\
\hline
\end{tabular}




\section{3) Oxazolidinones}

이 약제는 세균의 $50 \mathrm{~S}$ 리보솜과 결합하여 단백질 합성을 억제하여 항균 작용을 나타내는 항생제로 linezolid와 eperezolid 약제가 개발되어 있다. 새로운 oxazolidinone인 PNU-100480은 결핵균에 대한 항균 력이 isoniazid 및 rifampicin과 비슷하다고 알려져 있 으며, eperezolid는 결핵균에 항균력이 거의 없지만 linezolid은 결핵균에 어느 정도의 항균력이 있는 것 으로 알려져 있다. 우리나라에서 1 차 및 2 차 항결핵약 제의 치료에도 실패한 소위 만성 배균자들을 대상으 로 linezolid를 포함한 처방으로 치료를 시도하고 있 는데 아직 자료가 매우 제한적이긴 하지만 도말검사, 흉부 엑스선 그리고 임상상이 호전을 보이고 있다고 한다 ${ }^{11}$. 미래에 이 계통의 항생제에서 결핵균에 대한 항균력이 있는 항생제가 개발되기를 희망하고 있다.

\section{4) Nitromidazopyrans}

과거 결핵약제로서의 가능성에 관하여 많은 연구 가 이루어졌던 nitroimidazoles와 관련있는 약제이며, 특히 PA-824의 항결핵력에 대한 새로운 작용 기전과 isoniazid와 동등한 정도의 살균력이 있음이 알려졌다 12. 게다가 증식하지 않는 균에도 항균력이 있는 것처 럼 보여 치료기간을 단축시킬 수 있는 강력한 멸균제 로서의 가능성까지 있다.

\section{5) Clofazimine}

이 약제는 나병 치료제로 1962년부터 사용되고 있 다. 시험관내에서는 배지의 $\mathrm{pH}$ 에 따라 MICs $0.1-10 \mu$ $\mathrm{g} / \mathrm{ml}$ 범위에서 항결핵력을 가지고 있다. 쥐와 guinea pig 결핵 치료에서는 효과가 있었지만 rhesus monkey시험에서는 효과가 없었다. 이러한 차이는 균종 간의 최고 혈청농도의 차이에 기인하지 않나 생각하 고 있다. 사람에서의 항결핵력의 효과는 좀 더 평가가 필요하다.

\section{6) Macrolides}

Clarithromycin은 생체내와 시험관내에서 MICs 2 $\mu \mathrm{g} / \mathrm{ml}$ 미만으로 M. kansasii, M. fortuitum, M. chelonae, M. leprae, 그리고 M. avium complex 에 효
과가 있으며, 특히 AIDS환자의 파종성 M. avium complex 감염의 치료에 효과가 좋다. 결핵 치료제로 서는 추천되지 않고 있지만 2 차 항결핵 약제가 충분 치 않은 상태에서 시도되고 있다 ${ }^{6}$. Azithromycin과 roxithromycin도 비슷하다.

\section{7) Beta-Lactams}

Amoxicillin/clavulanate는 시험관내에서는 결핵균 에 항균력이 있다고 보고되었으나 쥐실험에서는 임 상적 효과가 증명되지 못했다. 이 약제도 2 차 항결핵 약제가 충분치 않은 상태에서 보조적인 약제로 시도 되고 있다 ${ }^{6}$.

\section{3. 면역요법(immunotherapy)}

일반적으로 결핵균 항원에 대한 숙주의 면역 반응 은 두가지 종류가 있는 것으로 알려져 있다: 하나는 격렬하게 염증 반응을 일으키면서 조직 파괴를 초래 하는 데 관여하고 있는 소위 '조직파괴 면역반응 (tissue-damaging immune response)'이라고도 불리 우는 지연과민(delayed-type hypersensitivity: DTH) 반응이고, 다른 하나는 염증 반응을 덜 일으키면서 결 핵균의 증식과 생존을 억제하는 데 관여하는 소위 ' 획득세포저항(acquired cellular resistance)'이라고도 불리우는 세포매개면역(cell-mediated immunity: CMI) 반응이다. 따라서 면역요법을 시도하는 기본 목 적은 이와 같은 두 종류의 면역 반응을 조절하여, 즉 $\mathrm{CMI}$ 를 증강시켜 결핵의 완치를 촉진하고, 다른 한편 으로는 DTH를 하향 조절하여 조직의 손상을 최대한 방지함과 동시에 환자의 증상을 호전시키는데 있다 ${ }^{13}$.

\section{1) 면역증강 요법}

숙주의 면역반응을 증강시켜 치료 효과를 기대하 는 치료의 대표적인 것이 사이토카인 요법이다. 단독 으로 시행하기 보다는 항결핵제를 투여하면서 보조 적인 면역증강 효과를 기대하면서 병용 투여하는 것 이 보통이며 대상이 되는 사이토카인은 당연히 Th1 경로에 관여하는 사이토카인들이다 ${ }^{14}$. 


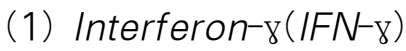

다제내성 결핵환자들을 대상으로 흡입 혹은 피하 로 주입하여 일시적인 균음전과 방사선학적인 호전 등이 있었다는 보고들이 있으나15-7, 결론적으로 결 핵을 완치시킬 수 있는 치료 방법이라기 보다는 제한 적이나마 환자를 호전시킬 수 있는 보조적인 요법으 로서는 유용한 것으로 인정되고 있다.

\section{(2) Interferon-a(IFN-a)}

많은 연구가 IFN-8에 관심을 두고 있지만 IFN-a 에 관한 연구도 있다. 이 연구 결과에 의하면 객담내 균수의 감소와 방사선학적 병변의 호전이 빠르게 나 타나고 증상(발열)도 빠르게 좋아져 $\mathrm{IFN}-a$ 도 $\mathrm{IFN}-\gamma$ 에 못지않게 부작용도 많지 않으면서 특히 TH1 경로 에서 $\mathrm{T}$ 세포 기능을 증강시킨다는 것을 보여주었다 ${ }^{18}$.

\section{(3) Mycobacterium vaccae:}

이 비결핵성 미코박테륨의 항원은 결핵균과는 달 리 숙주의 Th1 경로의 면역 반응을 주로 일으키거나 또는 활동성 결핵으로 인한 Th2 경로의 면역 반응을 Th1으로 전환시킨다는 고유의 면역학적 특성을 이용 하여 보다 더 세포면역의 방어적 면역 반응을 증강시 켜서 결핵 치료의 효과를 꾀하는 방법이다. 약제감수 성 결핵환자에서 항결핵약제와 M. vaccae를 함께 접 종하여 숙주의 면역반응을 증강시켜 특히 반휴면상 태로 있는 결핵 지속균(persisters)을 조기에 멸균시 켜 치료 기간을 단축시켜 보려는 시도도 있었으며, 일 부 연구자에서는 균음전과 방사선학적인 병변의 호 전 시기를 단축시켰다는 보고도 있었으나 임상대조 시험에서는 이 치료법의 효과를 증명하지 못했다 ${ }^{19}$.

\section{(4) 기타}

상기 이외에 Interleukin-12, Granulocyte-Macrophage Colony-Stimulating Factor (GM-CSF), Transfer Factor (TF). Inhibitors of Transforming $\mathrm{Gr}^{-}$ owth Factor- $\beta(\mathrm{TGF}-\beta)$ 등도 면역증강 효과로 미코 박테리아에 대한 항균력이 있는 지에 대한 연구들이 시행되고 있다.

\section{2) 면역하향조절 요법}

결핵균은 다른 병원성 세균과는 달리 내독소, 외독 소, 혹은 파괴성 효소를 분비하기 보다는 세포내로 침 범하여 집요하게 증식하기 때문에 이러한 균 자체를 제거하기 위한 숙주의 방어기전이 균이 침범한 조직 의 파괴로 나타나게 된다. 이러한 면역 반응으로 인하 여 조직이나 장기가 손상되면서 고열, 심한 발한, 탈 진, 식욕 부진, 그리고 체중 감소 등의 증상들이 나타 난다. 이러한 증상 등을 완화시키는 요법들에 관하여 간략하게 살펴본다.

\section{(1) Thalidomide}

이 약을 복용한 임산부의 태아에서 단지증이나 팔 다리 변형을 초래하는 것으로 악명이 높았으마 최근 에 TNF- $a$ 를 억제하는 효과가 있다는 것이 알려지면 서 다시 관심을 끌고 있다. $\mathrm{TNF}-\mathrm{a}$ 는 육아종 형성에 관여하는 필수 사이토카인으로 미코박테리아 침범에 대한 숙주의 방어면역에 매우 중요한 역할을 하고 있 다. 그러나 이 사이토카인이 과잉 생산되면 결핵 환자 에서 볼 수 있는 고열, 쇠약감, 피로, 야간 발한, 체중 감소와 폐조직 괴사등의 바람직하지 않은 병적인 증 상들이 초래된다.

Thalidomide ( $\mathrm{a}-N$-phthalimidoglutarimide)는 시 험관내에서 $\mathrm{IL}-1, \mathrm{IL}-6, \mathrm{GM}-\mathrm{CSF}$ 와 같은 타 사이토 카인의 생산을 방해하지 않으면서 선택적으로 단핵 세포로부터의 TNF- $\mathrm{a}$ 생산을 억제하고, 생체내에서는 증가된 혈청내 $\mathrm{TNF}-\mathrm{a}$ 농도를 정상화시킨다는 것이 알려졌다. Jane 등의 ${ }^{20}$ 대조임상연구에 의하면 결핵약 과 함께 thalidomide를 투여했을 때, 환자의 체중이 증가하였으며 TNF- $a$ 생산을 억제시키면서 다른 한 편으로는 $\mathrm{IFN}-\gamma$ 생산을 증가시키고 $\mathrm{PPD}$ 에 대한 $\mathrm{D}^{-}$ $\mathrm{TH}$ 의 반응도 방해하지 않음이 밝혀졌다. 이 약제는 태아 장애의 부작용 등으로 일부 사용의 제한은 있겠 지만 TNF- $\mathrm{a}$ 를 억제하는 작용은 향후 연구 대상으로 서 관심을 끌고 있다.

\section{(2) Pentoxifylline}

이 약제도 생체내와 시험관내에서 TNF-a 생산을 
억제한다는 것이 알려졌으며 $\mathrm{AIDS}$ 환자에서 $\mathrm{HIV}$ 복 제를 방해하는 효과가 있음이 밝혀졌으나 ${ }^{21}$, 결핵과 관련하여 그 임상적 유용성에 대하여는 연구는 아직 이루어지지 않았다.

\section{4. 새로운 백신}

새로운 백신으로는 크게 다음과 같은 4 종류가 시 도되고 있다.

\section{1) DNA vaccine}

항원성을 갖는 단백 대신에 그 단백을 합성하는 결 핵균의 유전자을 부호화(encoding)하는 DNA를 plasmid에 실어서 근육에 직접 주사하는 방법이 DNA vaccine이다. 오늘날 $\mathrm{DNA}$ 백신은 세균을 제거하는데 필수적으로 관여하는 Th1 면역 체계를 효율적으로 유도할 수 있기 때문에 결핵을 예방하는 유망한 전략 으로서 많은 연구가 시도되고 있다. 최근에 $\mathrm{Ag} 85 \mathrm{~A}$ 와 PstS-3 두가지 유전자로 구성된 이중-유전자 DNA vaccine을 화학치료와 함께 투여했을 때 치료 후의 재발(endogenous reactivation)과 재감염(exogenous reinfection)을 예방할 수 있다는 보고가 있었다 ${ }^{22}$.

\section{2) Live attenuated $M$. tuberculosis vaccines}

결핵균의 유전자 변형을 시도하여 숙주 내에서의 생존 시간을 증가시켜 항원성을 더 유지시키고, 이미 약독화된 생균을 더 약독화 시킴으로서 HIV감염자나 기타 면역억제 상태에서도 안전하게 결핵 예방에 사 용할 수 있는 여러 vaccines 개발 시도가 활발하게 진 행되고 있다.

\section{3) Recombinant BCG vaccines}

$\mathrm{BCG}$ 를 살아있는 vaccine vector로 이용하여 Th1 면역 체계를 보다 더 효율적으로 유도하기 위하여 유전자를 재조합하여 만든 백신이다. 방법으로는 특 정 항원 (예, $A g 85 B$ ) 이나 특정 사이토카인 예, $\mathrm{IL}-12)$ 에 관련된 유전자를 외부에서 삽입하거나, 또 는 내부의 관련된 유전자를 더욱 과발현시킴으로서 방어 면역을 더 잘 유도하도록 하여 결핵을 예방하고
자 하는 시도이다. 최근에 DNA 염기서열이 밝혀지 면서 이러한 시도에 많은 도움이 되고 있다. guinea pig 시험에서 이러한 recombinant vaccine이 전체적 으로 병변을 줄이고 병의 파종성 전파를 방지하는데 탁월한 효과가 있음을 보여주었다 ${ }^{23}$.

\section{4) Subunits}

Th1 면역 체계를 더 잘 유도할 수 있는 결핵균의 특정 단백질(subunits)에 대한 연구가 또한 활발한데 이 특정 단백질을 실험실에서 합성한 후에 근육에 주사하고 있다. 이러한 subunit vaccines은 종 특이 적이고 안전한 것이 장점이나, 단점은 숙주 내에서의 생존 기간이 짧아 항원성을 충분히 유지하지 못하는 것이다.

\section{5. 결 론}

의학이 발전하면서 결핵의 발병기전과 숙주의 방 어기전에 대한 우리의 이해가 넓어지면 질수록 우리 는 결핵의 예방이나 치료 분야의 발전을 가져올 수 있을 것이다. 현재의 6 개월 처방보다도 더 짧은 소위 초단기 처방(ultra-short-course regimens)과 다제내 성 결핵 문제를 해결할 수 있는 신 약제의 개발은 절 대적으로 필요한 상황이며, 다른 한편으로는 면역매 개 염증반응을 억제하여 임상 증상을 완화하고 장기 의 손상을 최소화하여 결핵 완치와 함께 그 후유증 (예, 폐기능 감소, 작업 능력 감소, 척추 변형, 신장기 능 장애)을 최소화시켜 육체적 정신적으로 건강한 상 태로 사회로 복귀시는 것도 향후 결핵치료 약제의 개 발 목적의 하나가 되어야 할 것이다.

아직까지는 결핵 치료제로서의 새로운 화합물이 발견되지 않고 있지만, 기존 항생제의 변경 혹은 기존 화학물질의 검색, 자연물질의 평가 등을 통하거나, 분자생물학적인 방법을 이용하여 특정한 생화학적 경로를 표적으로 한 새로운 약제가 개발될 가능성이 있다. 현재 quinolones계 항생제가 항결핵약제로서 가장 가능성이 높으며, 생체내에서의 지속적인 감염 균(persisters)을 목표로 하는 신약이 개발되면 기존 의 치료 기간을 획기적으로 줄일 수 있을 것이다. 최 
근 인간 및 결핵균의 유전체(genome)가 밝혀지면서 숙주의 감수성에 관여하는 인자와 결핵균의 다양한 단백질 합성에 관여하는 유전자에 근거한 신약 개발 의 가능성이 높아지고 있다. 면역 요법에 대하여 많은 연구들이 시행되고 있으며 일부 결과는 흥미를 끌기 에 충분하나 아직은 그 효과에 대하여 회의적이며 더 많은 연구가 필요한 상태이다.

\section{참 고 문 헌}

1. O'Brien RJ, Nunn PP. The need for new drugs against tuberculosis: obstacles, opportunities, and next steps. Am J Respir Crit Care Med 2001; 163: 1055-58

2. Cole ST, Brosch R, Parkhill J, Garnier T, Churcher C, Harris D, et al. Deciphering the biology of Mycobacterium tuberculosis from the complete genome sequence. Nature 1998; 393: 537-44

3. Telenti A. Genetics of drug resistance in tuberculosis. In: Iseman MD, Huitt GA, eds. Clinics in chest medicine. Philadelphia: WB Saunders, 1997: 55-64]

4. Lew WJ, Park YK, Kim HJ, Chang CH, Bai GH, Kim SK. The proportion of rifabutin-susceptible strains among rifampicin-resistant isolates and its specific rpoB mutations. Tuberc Respir Dis 2005; 59(3): 257-265

5. American Thoracic Society/Centers for Disease Control and Prevention/Infectious Diseases Society of America: Treatment of Tuberculosis. Am J Respir Crit Care Med 2003; 167: 603-62

6. Joia SM, Michael LR, Adrienne RS, J Keith J, Felix AV, Sonya SS, et al. Programmes and principles in treatment of multidrug-resistant tuberculosis. Lancet 2004; 363: 474-81

7. Tuberculosis Research Centre. Shortening short course chemotherapy: A randomised clinical trial for treatment of smear positive pulmonary tuberculosis with regimens using ofloxacin in the intensive phase. Ind J Tub 2002; 49: 27-38

8. Cambau E, Jarlier V. Resistance to quinolones in mycobacteria. Res Microbiol 1996; 147: 52-9

9. Gosling RD, Uiso LO, Sam NE, et al. The bactericidal activity of moxifloxacin in patients with pulmonary tuberculosis. Am J Respir Crit Care Med 2003; 168: $1342-5$

10. T.R. Sterling. The WHO/IUATLD diagnostic algorithm for tuberculosis and empiric fluoroquinolone use: potential pitfalls. Int J Tuberc Lung Dis 2004; 8(12):
1396-1400

11. Shim TS, Seoul Asan Medical Center (personal communication)

12. Stover CK, Warrener P, VanDevanter DR, Sherman $\mathrm{DR}$, Arain TM, Langhorne $\mathrm{MH}$, et al. A small-molecule nitroimidazopyran drug candidate for the treatment of tuberculosis. Nature 2000; 405: 962-66

13. Chapter 13. Vaccination to prevent tuberculosis and immunomodulatory therapy for persons with active disease. In: Iseman MD. A Clinician's guide to tuberculosis. Lippincott Williams \& Wilkins, 2000: 417-25

14. Han SK. The up-to-date of tuberculosis treatment. The annual course for respiratology 2002, Hanyang Medical School.

15. Kim EK, Shim TS, Lee JY, Oh YM, Lim CM, Lee SD, et al. The adjuvant effect of subcutaneous Interferon-gamma in the treatment of refractory multidrug-resistant pulmonary tuberculosis. Tuberc Respir Dis 2004; 57: 226-33

16. Park SK, Jun DS, Lee Y H, Lee DH. Treatment of multidrug-resistant pulmonary tuberculosis with Interferon-gamma subcutaneous injection. Tuberc Respir Dis 2003; 55 (suppl, 2): 84

17. Koh WJ, Ahn CH, Kim CH, Ahn YM, Lim SY, Seo JY. The therapeutic effect of 6-month inhaled Interferon-gamma treatment in intractible multi-drug resisdtant pulmonary tuberculosis. Tuberc Respir Dis 2001; 51 (suppl, 2): 116

18. Giosue S, Casarini M, Alemanno L, et al. Effects of aerosolized interferon-ain patients with pulmonary tuberculosis. Am J Respir Crit Care Med 1998; 158: 1156-62

19. Onyebujoh PC, Levin JB, Fourie PB, et al. Immunotherapy with Mycobacterium vaccae in patients with newly diagnosed pulmonary tuberculosis: a randomised controlled trial. Lancet 1999; 354: $116-9$

20. Jane MT, Utaiwan U, Anthomy M, Pasakorn A, Margaret B, Sanit M, et al. Thalidomide treatment reduces TNF-a production and enhances weight gain in patients with pulmonary tuberculosis. Molecular Medicine 1995; 1(4): 384-97

21. Wallis RS, Nsubuga P, Whalen C, Mugerwa RD. Pentoxifylline therapy in $\mathrm{HIV}$-seropositive persons with tuberculosis: a randomized, controlled trial. J Inf Dis 1996; 174: 727-33

22. Ha SJ, Jeon BY, Youn J, Kim SC, Cho SN, Sung YC. Protective effect of DNA vaccine during chemotherapy on reactivation and reinfection of Mycobacterium tuberculosis. Gene Therapy 2005: 1-5

23. Horwitz MA, Harth G, Dillon BJ, Maslesa-Galic S. Recombinant bacillus Calmette-Guerin (BCG) 
WJ Lew : The up-to-date of anti-tuberculosis treatment

vaccines expressing the Mycobacterium tuberculosis $30-\mathrm{kDA}$ major secretory protein induce greater protective immunity against tuberculosis than conventional BCG vaccines in a highly susceptible animal model. Proc Natl Acad Sci 2000; 97: 13853-8

24. Hans L Rieder. Interventions for tuberculosis control and elimination. IUATLD 2002, 153-69

25. Michael H Cynamon. Chemotherapeutic agents for Mycobacterial infections. In: Lloyd N Friedman, ed. Tuberculosis: current concepts and treatment, 2nd edition. CRC Press, 2001: 301-32 